\title{
ACTIVITY OF THE MICROSOMAL OXIDATION SYSTEM IN RAT LIVER UNDER THE INFLUENCE OF SODIUM FLUORIDE
}

Activity of the microsomal oxidation system in rat liver under the influence of sodium fluoride

I. Yu. Bagmut, I. L. Kolisnyk

Kharkiv Medical Academy of Postgraduate Education

e-mail: kolisnik.igor@ukr.net

Summary. The pathogenesis of fluoride intoxication at the molecular, cellular and functional levels has not been sufficiently studied. There are very few modern data on these issues, so they are contradictory, since the effects of this trace element are multifaceted and cannot be characterized unambiguously.

The aim of the study - to learn the state of the monooxygenase system of rat hepatocytes under conditions of the formation of fluoride intoxication.

Materials and Methods. In the experiment, we used 30 sexually mature rats $(N=30)$ of the Wistar population weighing 200-210 g for 1.5 months. Sodium fluoride solution was administered orally at doses of 1/10 DL50, which was $20 \mathrm{mg} / \mathrm{kg}$ of animal body weight.

Results. The results of experiments on the study of oxygen consumption by rat liver microsomes under fluoride intoxication indicated that the rate of endogenous respiration of microsomes, the rate of NADPH oxidation, the rate of $N A D H$ oxidation in the presence of EDTA, and the rate of lipid peroxidation increase under the influence of fluorides. Sodium fluoride stimulated an increase in all parameters of microsomal oxidation, except for cytochrome b5. It should be assumed that in this case there is an increase in the generation of reactive oxygen species, free radicals, which stimulate the development of free radical processes in the body and are, most likely, the leading link in oxidative stress.

Conclusions. These changes indicate a violation of the bioenergetics of hepatocytes associated with the mitochondrial apparatus and the development of hypoxic processes, which lead to a decrease in the activity of redox reactions occurring at the level of intracellular membranes and organelles.

Key words: sodium fluoride; microsomes; intoxication; liver; peroxidation; monooxygenase system.

\section{INTRODUCTION}

The medical and biological problem of the effect of fluoride on biosystems remains open, because the limited scientific basis of fluoride intoxication at
Активність системи мікросомального окиснення в печінці щурів під впливом фториду натрію

І. Ю. Багмут, І. Л. Колісник

Харківська медична академія післядипломної освіти

Резюме. Патогенез фрторидної інтоксикації на молекулярному, клітинному та фрункціональному рівнях недостатньо вивчений. Сучасних даних з чих питань дуже мало, тому вони суперечливі, оскільки ефекти цього мікроелемента багатогранні й не можуть бути однозначно охарактеризовані.

Мета дослідження - вивчити стан монооксигеназної системи гепатоцитів щурів в умовах інтоксикації фоторидом натрію.

Матеріали і методи. В експерименті ми використовували 30 статевозрілих щурів $(n=30)$ популяції Вiстар масою 200-210 г протягом 1,5 місячя. Розчин фрториду натрію вводили перорально у дозах 1/10 DL50, що становило 20 мг/кг маси тіла тварини.

Результати. Результати експериментів з дослідження споживання кисню мікросомами печінки щурів при фрторидній інтоксикації свідчили, що швидкість ендогенного дихання мікросом, швидкості окиснення НАДФН, швидкості окиснення НАДН при наявності ЕДТА, швидкості пероксидного окиснення ліпідів зростають під впливом фоторидів. Фторид натрію стимулював збільшення усіх параметрів мікросомального окиснення, крім цитохрому b5. Необхідно вважати, що при цьому має місце посилення генерації активних фрорм кисню, вільних радикалів, які стимулюють розвиток в організмі вільнорадикальних процесів і $є$ провідною ланкою оксидативного стресу.

Висновки. Зміни свідчать про порушення біоенергетики гепатоцитів, пов'язаного із мітохондріальним апаратом і розвитком гіпоксичних процесів, які ведуть до зниження активності окисно-відновних реакцій, що перебігають на рівні внутрішньоклітинних мембран і органел.

Ключові слова: фрторид натрію; мікросоми; інтоксикація; печінка; пероксидне окиснення; монооксигеназна система.

the molecular, cellular and functional levels with the definition of the pathophysiological mechanisms of intoxication under prolonged exposure to low doses of sodium fluoride [1]. Sodium fluoride has industrial 
synthesis and widespread use in the economic and industrial activities of society. Modern data on these issues are contradictory, however, the effects of sodium fluoride are multifaceted and require careful study of the effect of the chemical on the body. In conditions of exposure to negative factors of the environment and work environment to assess its reserve capabilities, the degree of resistance to adverse effects, the most appropriate methods for studying the modifying effect of chemical pollutants at the level of the microsomal oxidase system with a parallel study of a possible adverse effect at the level of membrane-structured enzymes [2].

The liver, lungs, skin, kidneys, spleen, adrenal glands, cells of the immune system and other organs are involved in the biotransformation of xenobiotics in the body. [3] However, the main enzyme systems involved in the transformation of xenobiotics are localized in hepatocytes, where, as a result of redox reactions and conjugation reactions, the chemical is modified and eliminated by excretory systems. These enzyme systems are localized in mitochondria, microsomes, or hyaloplasm. The detoxification of chemical compounds can proceed by the type of chemical oxidation, reduction, hydrolytic transformation, or by conjugation. The main laboratory carrying out these processes is the endoplasmic reticulum of liver cells, the microsomes of which contain a significant amount of ribonucleic acids, phospholipids and proteins [4]. However, in the existing scientific literature data on microsomal oxidation under conditions of long-term intake of fluorine compounds into the body have not been fully reflected. [5] The question of the biogenic effect of fluoride on the body remains open. The pathogenesis of fluoride intoxication at the molecular, cellular and functional levels has not been sufficiently studied. There are very few modern data on these issues, so they are contradictory, since the effects of this trace element are multifaceted and cannot be characterized unambiguously. [6]

The aim of the study was to learn the state of the monooxygenase system of rat hepatocytes under conditions of the formation of fluoride intoxication.

\section{MATERIALS AND METHODS}

The work was carried out in accordance with the plan of scientific research of the Kharkiv Medical Academy of Postgraduate Education of the Ministry of Health of Ukraine and is a fragment of the research work of the Department of Clinical Pathophysiology, Topographic Anatomy and Operative Surgery "Pathophysiological mechanisms of action of radiotoxins on the body and the principles of early diagnosis and correction" (state registration number 0117U000589, 2017-2021).

In the experiment, we used 30 sexually mature rats $(\mathrm{N}=30)$ of the Wistar population weighing 200
$210 \mathrm{~g}$ for 1.5 months. Sodium fluoride solution was administered orally at doses of $1 / 10$ DL50, which was $20 \mathrm{mg} / \mathrm{kg}$ of animal body weight. After the end of the experiment, the animals were decapitated with subsequent isolation of the liver, which was washed with saline and homogenized. When working with animals, we were guided by the requirements of the "European Convention for the Protection of Vertebrate Animals used in Experiments and Other Scientific Purposes" (Strasbourg, 1986), Law of Ukraine No. 3447-IV of February 21, 2006 "On the Protection of Animals from Cruelty." Homogenates were prepared in $100 \mathrm{Mm}$ Tris- $\mathrm{HCl}$ buffer, $\mathrm{pH}=7.4$.

The state of microsomal oxidation was assessed by respiratory and enzymatic activity, the content of cytochromes P-450 and b5. Microsomes of the endoplasmic reticulum of hepatocytes were isolated by the method of Komoth S. A., Narayan K. A. The protein content in the suspension was determined by the modified Lowry method. Oxygen consumption by the suspension of microsomes was recorded using a closed platinum oxygen Clarke electrode on a PA-3 polarograph. Measurements of NADPH-cytochrome $\mathrm{C}$-reductase and NADP-cytochrome C-reductase activity were recorded on a two-beam spectrophotometer "Specord" at a wavelength of $\lambda=550 \mathrm{~nm}$ by the method of Emster L. et al. The determination of cytochromes P-450 and b5 was carried out in a suspension of hepatocyte microsomes according to the method of Omura T., Sato R. In this case, the measurement of cytochromes b5 was based on determining the difference in the absorption of oxidized and reduced the established forms of hemoprotein, and cytochrome P-450 - by measuring the absorption of the complex, reduced cytochrome P-450 with carbon monoxide. The content of cytochromes was determined using an SF-46 spectrophotometer.

To determine the rate of the oxidized demethylation reaction, the microsomal suspension was added to the incubation medium, initiating it by adding $\mathrm{NADPH}$. The reaction was terminated with TCA acid, treated with alkali, the protein was precipitated by centrifugation, and the presence of $p$-nitrophenol was determined spectrophotometrically at a wavelength of $\lambda=436 \mathrm{~nm}$ on an SF-46 spectrophotometer. The resulting digital material was processed by statistical methods.

\section{RESULTS}

The study of the activity of O-demethylase, $\mathrm{NADPH}$-cytochrome C-reductase and $\mathrm{NADH}$-cytochrome C-reductase showed that with fluoride intoxication there is a significant increase in these parameters (Table 1).

The results of experiments on the study of oxygen consumption by rat liver microsomes under fluoride intoxication (Table 2) indicated that the rate 
Table 1. O-demethylase activity (nmol P-nitrophenol/min/mg protein) and NADH-NADPH-cytochrome C-reductase (nmol cytochrome $\mathrm{C} / \mathrm{min} / \mathrm{mg}$ protein) liver microsome activity

\begin{tabular}{l|c|c}
\hline \multirow{2}{*}{\multicolumn{1}{c|}{ Indicators }} & \multicolumn{2}{c}{ Groups of animals, number $(\mathrm{M} \pm \mathrm{m})$} \\
\cline { 2 - 3 } & Control & $\begin{array}{c}\text { Fluoride intoxication at doses of } 1 / 10 \\
\text { DL50 } \\
\mathrm{n}=13\end{array}$ \\
\hline O-demethylase & $\mathrm{n}=14$ & $14.5+1.2 \mathrm{l}$ \\
& $6.80+0.64$ & $\mathrm{P}<0.05$ \\
\hline NADPH cytochrome C reductase & & $270.20+40.61$ \\
& $190.8+21.60$ & $\mathrm{P}<0.05$ \\
\hline NADH cytochrome C reductase & & $1480.7+90.21$ \\
\end{tabular}

Table 2. Oxygen consumption by rat liver microsomes during fluoride intoxication $\left(\mathrm{nmol} \mathrm{O}_{2}\right)$

\begin{tabular}{l|c|c}
\hline \multirow{1}{*}{\multicolumn{1}{c|}{ Indicators }} & \multicolumn{2}{c}{ Groups of animals, number $(\mathrm{M} \pm \mathrm{n})$} \\
\cline { 2 - 3 } & $\mathrm{n}=14$ & $\begin{array}{c}\text { Fluoride intoxication at doses of } 1 / 10 \\
\text { DL50 } \\
\mathrm{n}=14\end{array}$ \\
\hline $\begin{array}{l}\text { Endogenous rate } \\
\text { respiration of microsomes }\end{array}$ & $1,50 \pm 0,27$ & $\begin{array}{c}3.25 \pm 0.271 \\
\mathrm{P}<0.05\end{array}$ \\
\hline Oxidation rate of NADPH & $3.20 \pm 0.41$ & $6.80 \pm 0.431$ \\
& & $\mathrm{P}<0.05$ \\
\hline $\begin{array}{l}\text { Oxidation rate } \\
\text { NADPH in the presence of EDTA }\end{array}$ & $2.80 \pm 0.36$ & $\begin{array}{c}7.40 \pm 0.351 \\
\mathrm{P}<0.05\end{array}$ \\
\hline $\begin{array}{l}\text { Peroxide rate } \\
\text { lipid oxidation }\end{array}$ & $0.44 \pm 0.12$ & $3.10 \pm 0.181$ \\
\hline
\end{tabular}

of endogenous respiration of microsomes, the rate of $\mathrm{NADPH}$ oxidation, the rate of NADH oxidation in the presence of EDTA, and the rate of lipid peroxidation increase under the influence of fluorides. Moreover, the latter have a more significant impact on all indicators. Attention is drawn to a significant acceleration of lipid peroxidation in comparison with the control by 7.0 times (fluoride intoxication).

The results of experiments on the study of the content of cytochrome monooxygenase system showed no differences with the control of the content of cytochrome bs in fluoride intoxication. There was a noticeable 1.95-fold increase in the concentration of cytochrome P-450 compared to the control. It should be noted that in this case, the presence of a specific effect of fluorides can be assumed.

\section{CONCLUSIONS}

Thus, the studies performed indicate that during these changes induced by fluorides, most parameters of microsomal oxidation increased quantitatively. Sodium fluoride at doses of 1/10 DL50 stimulated an increase in all parameters of microsomal oxidation, except for cytochrome b5. It should be assumed that in this case there is an increase in the generation of reactive oxygen species, free radicals, which stimulate the development of free radical processes in the body and are, most likely, the leading link in oxidative stress [7, 8]. Attention is also drawn to the fact of the specific effect of fluorides on long-term indicators of microsomal oxidation. These changes indicate a violation of the bioenergetics of hepatocytes associated with the mitochondrial apparatus and the development of hypoxic processes, which lead to a decrease in the activity of redox reactions occurring at the level of intracellular membranes and organelles [9]. 


\section{LIST OF LITERATURE}

1. Алехина Д. А. Влияние малых доз неорганических соединений фтора на уровень свободнорадикального окисления и внутриклеточных защитных систем в сердце, лёгких и печени / Д. А. Алехина, А. Г. Жукова, Т. Г. Сазонтова // Технологии живых систем. - 2016. Т. 13, № 6. - С. 49-56.

2. Казарина Л. Н. Медицинские аспекты комплексной профилактики и лечения фрлюороза у детей, проживающих в эндемичном районе / Л. Н. Казарина, А. Н. Самаркина, А. Е. Пурсанова // Медицинский альманах. - 2015. - № 3. - С. 172-175.

3. Экспериментальные исследования внутриклеточных защитных механизмов печени в развитии хронической фртористой интоксикации / А. Г. Жукова, Н. Н. Михайлова, Т. К. Ядыкина [и др.] // Медицина труда и промышленная экология. - 2016. - № 5. - С. 21-24.

4. Akimov O. Y. Influence of combined nitrate and fluoride intoxication on connective tissue disorders in rats gastric mucosa / O. Y. Akimov, A. V. Mischenko, V. O. Kostenko // Archives of the Balkan Medical Union. 2019. - Vol. 54 (3). - P. 11-15.

5. Yelins'ka A. M. Role of AP-1 transcriptional factor in development of oxidative and nitrosative stress in

\section{REFERENCES}

1. Alekhina DA, Zhukova AG, Sazontova TG. [Low dose of fluoride influences to free radical oxidation and intracellular protective systems in heart, lung and liver]. Tekhnologii zhyvykh sistem. 2016;13(6): 49-56. Russian.

2. Kazarina LN, Samarkina AN, Pursanova AE. [Medical aspects of complex prophylaxis and treatment of fluorosis in the case of children living in ende mic district]. Med almanakh. 2015;(3): 172-5. Russian

3. Zhukova AG, Mikhailova NN, Yadykina TK, Alekhina DA, Gorokhova LG, Romanenko DV, et al. [Experimental studies of intracellular liver protective mechanisms in development of chronic fluorine intoxication]. Meditsina truda i promysh ekol. 2016;5: 21-4. Russian

4. Akimov OY, Mischenko AV, Kostenko VO. Influence of combined nitrate and fluoride intoxication on connective tissue disorders in rats gastric mucosa. Archives of the Balkan Medical Union. 2019;54(3): 11-5.

5. Yelins'ka AM, Akimov OY, Kostenko VO. Role of AP-1 transcriptional factor in development of oxidative and nitrosative stress in periodontal tissues during systemic periodontal tissues during systemic inflammatory response / A. M. Yelins'ka, O. Y. Akimov, V. O. Kostenko // Ukrainian Biochemical Journal. - 2019. - Vol. 91 (1). - P. 80-85.

6. Akimov O. Ye. Correction of destructive changes in connective tissues of different organs during chronic nitrate and fluoride intoxication by nanosized silica oxide / O. Ye. Akimov, I. O. Kovalova, V. O. Kostenko // Journal of Education, Health and Sport. - 2019. - Vol. 9 (5). - P. 547-555.

7. The toxic impact of monosodium glutamate in rats / I. Krynytska, M. Marushchak, L. Naumova, L. Mazur // Jordan Medical Journal. - 2019. - Vol. 53 (2). - P. 91-101.

8. Акімов О. Є. Корекція оксидативного стресу в слизовій оболонці шлунка щурів ентеросорбентами різних класів за умов хронічної нітратно-срторидної інтоксикації / О. Є. Акімов, А. В. Міщенко, В. О. Костенко // Актуальні проблеми сучасної медицини: Вісник Української медичної стоматологічної академії. - 2018. - Т. 19(2). C. 103-106.

9. Akimov O. Ye. Superoxide and peroxynitrite production in gastric mucosa of rats under combined nitrate-fluoride intoxication / O. Ye. Akimov, V. O. Kostenko // Journal of the Grodno State Medical University. - 2018. Vol. 16 (6). - P. 730-734.

inflammatory response. Ukrainian Biochemical Journal. 2019;91(1): 80-5.

6. Akimov OYe, Kovalova IO, Kostenko VO. Correction of destructive changes in connective tissues of different organs during chronic nitrate and fluoride intoxication by nanosized silica oxide. Journal of Education, Health and Sport. 2019;9(5): 547-55.

7. Krynytska I, Marushchak M, Naumova L, Mazur L. The Toxic Impact of Monosodium Glutamate in Rats. Jordan Medical Journal. 2019;53(2): 91-101.

8. Akimov OYe, Mishchenko AV, Kostenko VO. [Correction of oxidative stress in gastric mucosa of rats by enterosorbents of different classesduring chronic nitrate fluoride intoxication]. Aktualni problemy suchasnoi medytsyny: Visnyk Ukrainskoi medychnoi stomatolohichnoi akademii. 2019;19(2): 103-6. DOI 10.31718/2077-1096.19.2.103. Ukrainian.

9. Akimov OYe, Kostenko VO. Superoxide and peroxynitrite production in gastric mucosa of rats under combined nitrate-fluoride intoxication. Journal of the Grodno State Medical University. 2018;16(6): 730-4. 